\title{
Reshaping European Union development policy: collective choices and the new global order
}

\author{
Reformulando a política de desenvolvimento da União Europeia: \\ escolhas coletivas e a nova ordem global
}

http://dx.doi.org/10.1590/0034-7329201500203

LUIS MAH*

Rev. Bras. Polít. Int. 58 (2): 44-64 [2015]

\section{Introduction}

The European Union (EU) has constructed its development policy largely on the discourse of moral responsibility and solidarity (European Commission, European Parliament and European Council 2006) ${ }^{1}$.This discourse is centred on the idea of a normative or ethical power (Aggestam, 2008) which shifts its role in the world from a positive role model to a proactive promoter of "global public goods". EU's recurrent focus is on poverty reduction and social issues, which underpins a self-portrayal as the guardian of the interests of the poor. This development policy is supported by strong financial resources and an implementing bureaucracy based in Brussels and EU delegations spread around the world.

The EU is a leading and active actor in the international aid architecture and its work is unique in the sense that, through the European Commission (EC), it provides not only direct donor support to recipient partner countries (in the form of grants, loans and equities), but also helps in the coordination of the development policy of its 28 member states. This work is facilitated by the EU delegations present in 136 countries (OECD 2012). The coordination and complementarity of the development policies of the EC and member states are particularly important due to the strong financial resources it involves and the potential development impact it can have if well implemented and managed by the EU. In 2010, the total aid

\footnotetext{
* Universidade de Lisboa, Instituto Superior de Economia e Gestão, Lisboa, Portugal (luismah@iseg.ulisboa.pt).

1 The definition of European Union that is followed in this article is the one set in the OECD DAC Peer Review 2012 (OECD, 2012): "The EU is an economic and political union of member states and has legal personality (...) The EU has a sui generis legal nature, and it is an individual donor in its own right, with its own development policy. Its legitimacy is dual, based on both the legitimacy of the governments of the member states that are represented in the Council (i.e. indirect legitimacy) and the legitimacy of the European Parliament that is directly elected by EU citizens (i.e. direct legitimacy)."
} 
provided by the EU (EC and member states) reached more than USD 90 billion, making it the largest ODA donor (OECD 2012).

The EC has been seeking to design and implement a common EU development policy as a way to strengthen EU aid effectiveness, coordination and complementarity, to limit waste in resources, to avoid duplication, and to reduce the negative impacts. These are usually coordinated with other high-income donors in the context of the Organisation for Economic Co-operation and Development (OECD) Development Assistance Committee (OECD-DAC), which has thus far been the main institutional framework for steering and monitoring the international aid agenda, in particular the aid effectiveness one. In recent years, increasingly associated with this agenda is the EU normative push and insistence on reforms in the area of good governance by recipient partners. The good governance focus is also linked to the increasing call to respect the principle of ownership which affirms that aid recipients should have the capacity to autonomously decide on their own development policies as set out by the 2005 Paris Declaration on Aid Effectiveness. While there were attempts since the late 1950s to produce a common development policy, it is only in the early 2000s that major efforts were undertaken to come up with common EU development policy goals and principles (Carbone 2010).

The EU development policy can be analysed according to three periods. The first period (between the late 1950s and the mid-1980s) had the Lomé Convention (1975-2000) at the cornerstone of the EU development policy. This Convention regulated the relations between the EU and the so-called ACP Group (African, Caribbean and Pacific countries) and it was described as a generous aid and trade programme under a "genuine partnership" in which the involving parts were regarded as equals (Carbone 2010). The Lomé Convention showed an EU development policy that distinguished itself for its political neutrality and noninterference. The second period (between the late 1980s and late 1990s) is marked by the Maastricht Treaty, which entered into force in November 1993, leading the EU to take the first steps towards a common foreign and security policy (CFSP) as a way to increase the Union's role on the global stage. The EU development policy expanded beyond the ACP-based sphere to include all developing regions. This was also the period in which the EU decided to adopt the mainstream Washington consensus on development, i.e., primacy to economic over political conditions for the disbursement of aid. Additionally, the non-reciprocal trade regime applied to the ACP Group started to be challenged as it was incompatible with the World Trade Organisation rules (Carbone 2010).

Finally, since the early 2000s a series of agreements and documents have marked the entrance of the EU into a novel period. It began with the Cotonou Agreement (2000-2020) to replace and introduce important changes in the aid and trade procedures formerly set in the Lomé Convention. EU aid disbursement became conditional not only on a needs-base, but also according to performance in implementing jointly agreed country strategy papers (CSPs). Additionally, the 
EU began to push for new trade agreements, or Economic Partnership Agreements (EPAs), but this process remains unfinished and highly criticised by African partner regions in particular. Another change introduced in the Cotonou Agreement was the strengthening of the political dimension between the EU and the ACP Group through new issues such as security and migration (Carbone 2013).

The Agreement was followed in 2005 by the European Consensus on Development (European Commission, European Parliament and European Council, 2006) and the 2007 Code of Conduct on Complementarity and Division of Labour. While the former set common strategic norms (such as participation, political dialogue, partnership and ownership), objectives and plans of action for the EU development policy, the latter focus on EU better aid management calling on all member states to concentrate their aid activities in a limited number of countries as well as on a limited number of sectors per recipient partner (European Commission 2007). Both are regarded as turning points for EU coordination and complementarity in terms of development policy.

\section{Reforming the EU External Action and Development Policy}

The Treaty of Lisbon came into force in December 2009 to create new institutions and legal instruments to fortify the EU external action and, consequently, to reshape the EU development policy (European Union 2007). The Treaty defines the respective competences of the EU institutions and member states setting a complex legal and institutional framework for development cooperation and humanitarian aid, areas to be shared by the EU institutions and member states. Development policy is now part of the EU's areas of external action and development cooperation is clearly described in Articles 208 to 211. In Article 208 it acknowledges (1) poverty fighting as the primary goal of EU development policy and (2) the need to strengthen the role of policy coherence for development (PCD) by the EU. PCD is a concept designed to maximise the positive impacts of policies for development by linking, for example, European immigration policy and development or climate change and development. This is expected to improve both the effectiveness and credibility of European development cooperation.

The Treaty created the new post of High Representative (HR) for Foreign Affairs and Security Policy (FASP) (who is simultaneously vice-president of the European Commission) and the European External Action Service (EEAS) to provide more strength and consistency to the EU global activities (Vanhoonacker and Pomorska 2013). Also at the European Commission, a new Directorate General for Development and Cooperation EuropeAid (or DG DEVCO) was set in January 2011 as a result of the merger of parts of the former Directorate General for Development and EuropeAid Cooperation Office. On its website it states that: "EuropeAid Development and Cooperation is responsible for designing European development policy and delivering aid throughout the world. EuropeAid delivers 
aid through a set of financial instruments with a focus on ensuring the quality of $\mathrm{EU}$ aid and its effectiveness. An active and proactive player in the development field, we promote good governance, human and economic development and tackle universal issues, such as fighting hunger and preserving natural resources" (European Commission 2013). This move aims to make DG DEVCO a "one stop shop" for all stakeholders in the field of development cooperation. The Treaty strengthened also the role of the European Parliament, in particular budgetary powers, in monitoring and scrutinising the EU development policy.

As it stands, EEAS and DG DEVCO are both in charge of the programming for three European development aid funds: the geographical components of the Development Cooperation Instrument (DCI), the European Development Fund (EDF) and the European Neighbourhood and Partnership Instrument (ENPI). EEAS leads the first three phases of the programming: (1) country allocation; (2) strategic reports for each country and region; (3) national and regional indicative programmes. These are then submitted to the High Representative (HR) for Foreign Affairs and Security Policy, who is simultaneously vice-president of the European Commission, and to Development Commissioner to be approved by the College of Commissioners. Once approved, the programmes, DG DEVCO becomes the sole responsible for the next and last two phases of the programming: (4) annual action plans, and (5) implementation of the programmes. Yet the Development Commissioner holds full authority of the joint programming cycle (European Union External Service 2013; Faure, Gavas and Maxwell 2013).

However, as the latest European Union OECD DAC Peer Review (2012) states, this attempt to strengthen the coordination and complementarity of EU development policy is far from achieved: "Despite progress, developing a cohesive approach to meeting development cooperation commitments and speaking with a unified voice in the international arena is still challenging". The OECD DAC Peer Review stresses also that the new institutional framework set by the Treaty of Lisbon raises "some associated risks" by building more complexity in the EU development policy implemented by the EEAS. The process of creation of the EEAS, as pointed by Michael Smith (2013), has been marred by intergovernmental, bureaucratic and priority conflicts that challenges the coherence and effectiveness of EU foreign policy. While the EEAS (positioned outside the Commission, but with its work completely under the Commission systems) has authority for the multiannual phase of development programming and works jointly with DG DEVCO, this DG remains responsible for managing the budget, designing and implementing the programme.

Another important change introduced by the Treaty of Lisbon was the strengthening of the role played by the European Parliament, in particular, legislative and budget powers identical to the European Council. It is also the guardian of the civil, political, economic and social rights as set by the EU Chart of Fundamental Rights in the Treaty. At the level of development cooperation, 
the Parliament votes, revises and monitors the EU development budget as well as holds regular audiences with the Development Commissioner.

In summary, the EU development policy is currently undergoing important changes in operational terms (within EU institutions and between the EC and member states) brought about by the Treaty of Lisbon and in terms of its future orientations. The driving force behind most of this changing process seems to be more bureaucratic than political, and progress has been slow. The EU member states seem to lack true ownership of this normative setup led by the EC. It is still difficult to see, in practice, a real common strategy based on a common identification of policy interests and priorities. There is also no clear articulation between the developmental and economic dimensions, which often means that economic policy and interests contradict and undermine development policy (Cornelissen 2010).

\section{Facing a new global order}

As the EU proceeds with reforming the institutional and legal frameworks underpinning the Union's external action, the impact of the emergence of new donors from Latin America, Middle East and Asia with alternative models of development cooperation started to be felt in the global aid agenda and arena (Walz and Ramachandran 2011; Mawdsley 2012; Hackenesch and Janus 2013; Gore 2013). While many of the prosperous traditional OECD-DAC donors have been hit hard by the economic and financial crises of recent years, which has forced them to decrease their aid budgets, emerging donors like China, Brazil, India or Turkey have increased their roles as aid donors. The fundamental difference between the traditional and emerging donors lies in the fact that the latter regard themselves as interested parties in a mutually beneficial relationship with their development partner countries. They reject the notion that some countries are 'donors' and others 'recipients'. These new actors, albeit diverse approaches, are challenging the EU's global weight and traditional leadership role as donor and are stimulating a reconsideration of its development policies.

Due to their different development models, these emerging donors tend to be less concerned with the normative discourse or the policy process of aid recipients and more focused on mutual economic gains from the relationship. In this scenario the principle of ownership takes on a different framework, where recipient countries have the status of equal partners: decisions are taken on the basis of projects or specific investments, with less scrutiny on macro policy.

It is possible to identify three major features in the way emerging donors design and implement their development policies (Smith, Yamashiro Fordelone et al. 2010; Mawdsley 2012; Castillejo 2014). First, they like to state that they do not attach policy conditions to their development programmes. They repeatedly claim not to interfere in the domestic affairs of partner countries and that they respect the 
principles of 'national sovereignty' and 'solidarity'. By presenting themselves in this way they differ from traditional donors, who tend to impose conditions in terms of macro-economic reforms and good governance. Secondly, emerging donors prefer to provide technical cooperation in the form of the direct implementation of the projects agreed with partner countries. Traditional donors, on the other hand, seek to influence the beneficiary's micromanagement of development affairs and interfere in the policy process. Finally, emerging donors tend to provide financial support (concessional loans rather than grants) and trade access (Smith, Yamashiro Fordelone et al. 2010; ECOSOC 2008). In contrast, traditional donors continue to offer long negotiations to allow access to their markets. This brings to the fore the difficulties that exist in the relationship between the EU and its development partners, difficulties that are closely related to the widely criticised imposition of development models and policy conditionality based on such imperatives as a good governance agenda.

The 2011 Busan Forum on Aid Effectiveness was a negotiation arena where these differences between traditional donors and emerging donors were confronted. The EU presented a weak position, reflecting a lack of leadership, and conceded to many of the emerging donors' demands in order to join the partnership and sign the document. This contrasted clearly with the leading role that the EU had played in the two previous High Level Forums (HLFs) in Paris and Accra. As CONCORD, the European NGO confederation for relief and development, posits: "the European Union was a ghost at the global aid summit" (CONCORD 2012a). The final document reflects the concessions to emerging donors and, hence, the shift from an aid effectiveness agenda to an effective development cooperation agenda, marked by the voluntary nature of the emerging donors' commitments (Glennie 2011).

The declaration that came out from Busan (OECD 2011), embodies a change in the logic behind the aid effectiveness agenda on four points. First, it moves from a focus on aid to one of cooperation and effective development. Second, it recognises the status of developing countries as de facto partners, as a way of acknowledging the mutual benefits of the partnership. Third, it decentralises the activities involving norm adaptation and monitoring to the field level and to other organisations that, in contrast to the OECD-DAC, are not 'donor-driven forums'. Finally, it establishes flexibility, enabling the involvement of emerging donors who do not agree with the norms developed in the context of the OECD-DAC. Busan may be seen as a turning point in the global aid arena by recognising the growing and important role of the new donors vis-à-vis the traditional donors.

\section{In search of a new EU development policy}

The Agenda for Change, launched in 2011 by the European Union, coinciding with the Busan Forum, emphasises two main pillars for EU development 
policy: (1) the promotion of human rights, democracy, rule of law and good governance and (2) the promotion of inclusive and sustainable growth. It proposes four major shifts: more conditionality concerning good governance and human rights; a focus on growth and the role of the private sector; a new concept of differentiated development partnerships with new aid allocation criteria; increased coordination of EU policies (European Commission 2011b). An essential part of the debate around this set of proposals is the issue of whether development objectives should be broadened to cover inclusive economic development, growth and employment creation or whether the focus should remain strictly on poverty reduction (HTSPE 2011).

On the first major shift, the European Parliament, as the guardian of the normative system and with a strong vetting power on the EU development policy following the Lisbon Treaty, has warned against the EU emulating the methods of such emerging donors like China, "since that would not necessarily be compatible with the EU's values, principles and long-term interests" (European Parliament 2008; Smith 2011) and voiced its support for conditionality in EU cooperation with its partners with regard to human rights and environmental standards. Despite the European Parliament's normative discourse, many of the $\mathrm{EU}$ policies continue to undermine the EU move to build more policy coherence for development (PCD). While the focus was initially on more than ten policy areas, in the proposed Agenda for Change (European Commission 2011b), PCD is related to global interests and only the security-development and migrationdevelopment links are emphasised. This reflects the tendency towards European self-interest/Europe's own interests and securitarian concerns (Gibert and Bagayoko 2009) and conflicts with the normative focus on needs-driven aid allocation and ownership. This modification reveals how the discourse seems to be following a reasoning of mutual benefit, in contrast to the previous approach that was much more paternalistic and anchored in the benefits that the developing countries had from EU cooperation. However, despite these tendencies on the part of the EC, the language of mutual interest was not taken up in the final document of the Agenda for Change, which postulates that the ground might not be ripe for such fundamental changes of the EU development policy.

The second major shift in this Agenda for Change is the clear interest of the $\mathrm{EU}$ in engaging the private sector to promote sustainable and inclusive growth. This means an updating of the EU policies on private sector development that dates back to 2003 and a DG DEVCO with better knowledge management processes and expertise sharing with other EU Directorates General (OECD DAC 2012). According to this proposal, the EU plans to use more ODA to mobilise private investment in developing countries (European Commission 2014). By doing this, the EU seems to be following the steps of the new emerging donors that tend to use their development cooperation programmes to financially support the entry of their domestic businesses in new markets in Africa, Asia and Latin America. As stated 
by AidWatch, (CONCORD 2012) that monitors and make recommendations on EU aid effectiveness, when analysing the proposed Agenda for Change: "Few credible actions are envisaged to regulate private investment effectively in order to improve its social returns and overall development effectiveness, however, so the new focus on the private sector is likely to result in EU investors benefiting from EU aid, rather than poor countries benefiting from private investment."

The third major shift proposed by the Agenda for Change introduces an attempt to differentiate development partnerships that will lead to significant changes in particular in the relationships between the EU and upper-middle income (UMICs) and high-income countries (HICs). Krätke (2013) states that this new approach — differentiation — will affect countries such as Brazil, China, India, Mexico, Thailand or Indonesia since they will stop receiving bilateral assistance. They might, nevertheless, receive funding through other EU thematic programmes and other instruments). Interestingly, these countries happen to also be some of the leading emerging donors. The selection is to be based in four criteria: country's needs, country's capacity, country's commitments and performance, and potential EU impact. Both the country's commitment to and its record on human rights, democracy and the rule of law, as well as its ability to conduct reforms and to meet the demands and needs of its people are going to determine the ODA levels it may receive from the EU. This raises the question of how the EU can cut aid to influential emerging countries while working with them to address global challenges (Gavas 2012).

The last and fourth major shift focuses on increased coordination of EU development policy taking forward the idea of joint programming. The main goal of joint programming is to build a common framework to improve the harmonisation, coordination and division of labour of EU institutions and member states' development policies. The other expected positive effect is to improve recipient partner country's ownership, alignment with national development plans and country systems as well as aid predictability. The EU has launched a pilot programme on joint programming in six countries (Ethiopia, Ghana, Guatemala, Laos, Mali and Rwanda) for the upcoming country programming period, 2014-2020 (CONCORD 2012). The process is still in its early days so there is very little information on its actual impact so far.

\section{The contradictions between discourse and practice of the EU development policy}

Unlike the approach undertaken by emerging donors that seems very clear and straightforward (outlined above), there are three essential contradictions between the EU discourse and practice that continue to be unsolved with the Agenda for Change to create problems in the relationship with its partner countries and distort the political balance (Carbone 2010a): (1) moral responsibility versus 
economic interests; (2) social agenda versus economic growth; and (3) ownership versus conditionality.

\section{Contradiction I: moral responsibility versus economic interests}

While the EU development policy has been built around a normative-based discourse, the frequent disjuncture between discourse and practice helps to undermine the standing of the EU vis-à-vis their partners. One example is tied aid or aid disbursement on the condition that it be used to procure goods or services from a specific country. This is commonly view as leading not only to increasing costs in implementing a development project but also in administrative costs. By untying aid, donors are offering recipient countries to use their aid to procure goods and services from almost any country that offer better "value for money" and suit their needs. The EU likes to trumpet its efforts to "untie" aid and claims to tie only about $10 \%$ of it (HTSPE 2009), but much remains to be done in that regard as pointed out by a EURODAD 2011 report, the European Network on Debt and Development of 54 NGOS from 19 countries (EURODAD 2011).

Another example of the contradiction between the EU discourse and practice is provided by the ongoing EPAs negotiations and a key trade instrument within the Cotonou Agreement. With the EPAs, the EU wants the ACP countries to open their doors to European goods and services in return for duty-free market to European consumer and commodities market. The negotiations started in 2002 and were expected to conclude in 2007. Instead, until 25 May 2015, and according to the European Commission's trade website on the EPAs (http://ec.europa.eu/ trade/policy/countries-and-regions/development/economic-partnerships/), none of the African regional communities has already signed and ratified an EPA. African leaders have argued that the EPAs will destroy their nascent industries and hamper the needed structural transformation of the economy by allowing the entrance of European goods and services. In an EPA Negotiations Coordination Meeting organised by the African Union in Arusha (Tanzania), between the 17 and 18 May 2012, which aimed at reviewing and assessing the current state of the negotiations, the African Union's response was clear (African Union, 2012). Despite the European Commission's announced plans, the meeting adopted the following recommendations among others:

ix. There is need for a rethink of EPA negotiations taking into account current developments and the rise of emerging economies. The new issues (geographical indications, investment, Trade and Environment, etc) that are being introduced in the negotiations should not be negotiated to ensure the interests of African countries are not compromised

$x$. The African regions negotiating EPAs and the African Union should continue to collectively maintain their positions on the following: Most Favoured 
Nation (MFN), Export Taxes, Safeguards, Rules of Origin, Non-Execution Clause, which are considered to be of critical importance to the development aspirations of regions and the continent as a whole.

The increasing agency of developing countries to the usual beneficiaries of EU development aid is already seen as a major reason behind the reducing asymmetrical power between the EU and the developing world (Carbone 2013a), and the role played by the new donors cannot be behind this agency is hard to challenge. Additionally, this new context is expected to further enhance this contradiction as the EU tries to adjust its development policy in response to the continent's financial and economic crisis. The impact of this crisis in the EU development policy can be seen in several ways: it has reduced the material weight of the EU in traditional spheres of economic and political influence; it has created pressure from the constituencies of donor governments to focus on achieving better results ('value for money'), which sometimes entails more micromanagement from donors; and it has meant a search for new sources of income outside the EU by accessing new markets and resources within a growing global competition. This new international and regional context has led to an increasing reflection on what should be the future of EU foreign policy (European Think Tanks Group 2014; Fagersten et al. 2014; Witney et al. 2014).

\section{Contradiction II: social agenda versus economic growth}

Given the colonial past of several of its member states, the EU has felt a moral obligation to push for poverty reduction as its main goal in terms of development policy and a focus on the achievement of the social-based Millennium Development Goals (MDGs). In some respects, the EU acts as the conscience of governments which it regards to have failed to prioritise the concerns of the poor and are instead more concerned with growth and the satisfaction of the interests of local elites. However, this does not necessarily improve the relationship between the EU and its partner countries with the latter frequently accusing traditional donors like the EU of micro-management and interference in their internal politics (Glenn 2008; Faust 2010). The EPA issue also reflects this second contradiction as the EU is seen as pushing for the implementation of a neoliberal model of economic development and capitalism that are seen as responsible for the poverty in developing countries (Craig and Porter 2006; Blunt, Turner et al. 2011). The EU appears to be trapped in its own ambivalence regarding the impact of its economic agenda in terms of social outcomes: on the one hand it asks for state deregulation and liberalisation, on the other hand it asks for a social focus on poverty issues. In general, the link between trade and development is becoming a key factor in defining the future of European development policy. But as stated by Carbone and Orbie (2014), while the EU is aware of the fact that there should be a nexus between trade and development, 
it does not have a "clear or distinctive view on how this should happen". This is particularly evident for Africa. Europe is now seeing Africa as a potential market, as well as a source of natural resources. This is something new, as Africa did not weigh much in EU foreign investment. This business-oriented perspective will create challenges for the normative position, but Europe will be forced to retain and enhance its influence in the face of the emerging donors' models.

While Africa is not traditionally a major trading partner for Europe, European countries remain among the major trade partners of the continent. Although China and the USA are ranked at the top, if EU countries were taken together they would far exceed the two leading partners (African Development Bank 2011a). After 2004, the commercial ties between Africa and the EU increased rapidly, only to fall back in the aftermath of the economic and financial crisis that hit Europe. For the past eight years, the value of non-EU trade in goods with Africa has risen substantially, with imports from Africa (mainly energy products) consistently higher than exports to it (especially machinery and transport equipment). Between 2008 and 2009, the value of EU27 imports from Africa decreased by 33\% (from EUR 158 billion to EUR 106 billion), and EU27 exports to Africa fell by $10 \%$ (from EUR 119 billion to EUR 107 billion) (Eurostat 2010).

The growing aid ties between emerging donors, in particular China, and Africa are undoubtedly related to their needs in terms of the primary commodities required to feed their economic growth. However, the picture that seems to be emerging is that they are also tapping into the growing African consumer market and thus rivaling Europe and the USA. A recent report from the Standard Bank (Freemantle and Stevens 2012) shows that, since 2008, Korea (+48\%), India $(+45 \%)$ and China $(+38 \%)$, along with Malaysia, have been the leaders in consumer imports into Africa. In contrast, the major European economies have struggled to compete with the new Asian competitors in the African market: Italy (-14.2\%), Spain $(-3.3 \%)$, Germany $(-2.3 \%)$ and the U.K $(-2.2 \%)$ have all lost consumer market share since 2008 .

The other novelty of emerging donors in Africa lies in the fact that they were especially timely in intervening in another sector that had been neglected by the Europeans and Americans, despite the fact that it was a priority for African countries: the building of large scale infrastructure projects on the continent. This has included the rehabilitation of roads and railways, the construction of new transport corridors and hydropower dams. These infrastructures are crucial to enable the continent to transform the economic structure and build an industrial sector to benefit from growing regional and global trade markets beyond commodities. Although emerging donors support poverty reduction policies, they are less doctrinaire on how to get there and steer clear of macroeconomic policy-making (Walz and Ramachandran 2011: 17-18). They pursue a strategy of non-involvement, leaving the partner countries to decide on investment in social 
areas. Economic interaction is driven by a notion of gains on both sides, based on what is termed win-win partnerships. In short, the imposition of economic conditionalities enhances the ambivalence between interests and norms that brings unease to the relationship between the EU and its recipient partner countries. This contrasts with the behaviour of emerging donors, who develop looser relations and are not so intrusive.

Some EU member states, however, do not seem to be shying away from putting aid and economic interests together in their development policies. Richard Moncrieff (2012) states clearly when analysing the former French presidency led by Nicolas Sarkzoy that: "French aid has been one of the support mechanisms of French commercial presence on the continent, whether formally through aid tied to commercial contracts, or informally since the 'untying' of French aid". It is still too early to assess whether or not it has changed with the new Presidency led by François Hollande. The UK, under the Tory government led by David Cameron, has presented a new strategy for engagement with Africa. The Foreign and Commonwealth Office (FCO) is now leading the Department of International Development (DFID), which, over the past ten years, dominated UK policy for Africa. This represents the recognition that development objectives will now be linked to UK interests on the continent, including trade (Cargill 2011). Bayne (Bayne and Woolcock 2011) argues that governments try to reconcile three types of tension in economic diplomacy: between economics and politics; between international and domestic pressures; between governments and other forces. In the specific context of development policy, we would include an additional tension between development aid norms and economic interests. Even with the increasing role that the EU's Agenda for Change is placing on the role of the private sector for development, the EU, as a collective actor, continues to strive to build a normative discourse for its development policy that separates economic interests from development concerns (even if the practice fails to match the discourse).

\section{Contradiction III: ownership versus good governance}

Finally, the increasing call for greater ownership of development policies by recipient partners is closely linked to the good governance agenda which has been pursued by the EU since the early 1990s. The concept, borrowed from the World Bank, emerged as one of the objectives of the EU development policy. This became more evident in the negotiations between the EU and the ACP Group leading to the Cotonou Agreement in 2000. If the Lomé Convention (1975-2000) characterised itself for EU political neutrality, the Cotonou Agreement (20002020) revealed a EC and member states eager to have good governance included in the new accord (Carbone 2010a). It was also at this point that the framework of aid effectiveness was established and reforms in the area of good governance 
came to be seen as a sine qua non condition for aid effectiveness and for the successful adoption of General Budget Support (GBS) as the preferred modality for disbursing aid among European donors and respecting the principle of ownership. This modality implies that the country has transparent systems and that it has governance and accountability structures in place and in operation - ideally, for its citizens in the first place, though also for the donors. Yet, traditional donors, like the EU, have hesitated to provide it, in practice, due to the difficulties in ensuring good governance. This is particularly so when many developing countries are demonstrating solid economic growth, but continued and sometimes even rising levels of poverty (Casse and Jensen 2009). This problem is connected with the lack of democratic accountability to their citizens and parliaments. Traditional donors have insisted on democratisation and devised governance matrixes to try to ensure some level of accountability but they have resulted in further criticism of micromanagement and interference in the internal affairs of developing countries (Carmody 2008). This is also linked to the lack of focus on pro-poor growth and the absence of redistributive policies in some developing countries, priorities that the EU has tried to stimulate. All these are seen as intrusive methods that are contrary to the commitment to the ownership of development, or as Börzel and Christine Hackenesh (2013) put it clearly: "While conditionality is more effective in making African governments address governance issues, it undermines the legitimacy of the EU's development cooperation, which emphasizes partnership and ownership".

The EU seems to be aiming at revising its development policy on this issue with the adoption, in August 2006, of a new approach on "democratic governance" described to be "pragmatic" and based "on dialogue and capacity building"(Carbone 2010a). This new EC communication presents particular features: (1) democratic governance is only a means towards poverty eradication as the main goal of EU development policy; (2) good governance cannot be imposed from outside in respect of the principle of ownership; (3) an understanding of good governance that goes beyond being a merely technocratic issue (focused mainly on the fight against poverty) to embrace a more holistic view that includes also issues like access to health, education and justice, pluralism in the media, parliament activities, and the management of public budgets and natural resources; (4) harmonisation of $\mathrm{EC}$ and member states approaches to good governance; and (5) launching of a new incentive-based mechanism (European Community Governance Incentive Tranche - ECGIT) to reward countries for their governance achievements. The reward would be offered following the production of a Governance Profile by the EC and an Action Plan by the recipient partner (Carbone 2010a; European Commission 2013a).

Yet, an independent study commissioned by the EC, in the end of 2010, to review the "democratic governance" initiative (external) has revealed its shortcomings (European Commission 2013): 
Limited ownership of the GI process; 2) insufficient alignment between the GI and already existing governance processes and plans in a given country; 3) inflexibility of the tools; 4) political and institutional capacity constraints on both sides; 5) limited influence of the financial incentive alone; 6 ) insufficient harmonisation within the EU". The study also proposed a series of recommendations: "1) support for democratic governance is to be embedded in local realities; 2) the role of regional or continental initiatives on governance; 3 ) engagement with civil society; 4) developing and enhancing existing local capacities; 5) rethink the incentives and conditionalities; 6) performance assessment; 7) flexibility and 8) strengthen harmonisation within the EU.

The promotion of good governance remains a pillar of the EU development policies but as shown above EU institutions seem to be unsure on how to implement it and to address it when dealing with countries which receive EU aid but are far from complying with what is understood to be EU standards for good governance. Additionally, the Treaty of Lisbon offers the European Parliament - the EU guardian of the civil, political and social rights - a strong voice and vote on EU development policies.

\section{Conclusion}

The emergence of new global economic powers (that are increasingly becoming donors), the changing multilateral aid architecture under pressure to offer more space and voice to developing countries, and the challenge to marketoriented economic models dominant in Europe and the US following the 2008 crisis can be highlighted as the main features of the international aid arena. These features have had an impact in the development discourse to one that "places more emphasis on mutual interest, global risks, global commons, and 'beyond aid' approaches" (ODI 2013).

With this new international aid landscape in place, the EU development policy is undergoing structural changes in its policy orientations and operationalisation as mentioned above. It is too early to assess the impact of the changes, but the EU seems to be now far from its instrumental role in shaping international development as it was in the early 2000s, when it pushed for key global policy issues on financing for development, aid effectiveness and coordination, and policy coherence for development. The new institutional framework set by the Treaty of Lisbon seems to have generated mixed feelings. For the OECD-DAC, it represents an important step forward for the EU development policy as it seeks to build more coherence, complementarity and unity between the development work pursed by the EC and Member States. But others like CONCORD have warned that, while development policy has been strengthened in the Treaty, the interpretation and implementation of the new provisions might lead it to be instrumentalised to pursue EU foreign policy goals (CONCORD 2012a). 
The way this new institutional framework will be operationalised is crucial if the EU wants to manage strategic relationships in an increasingly crowded development aid landscape with a myriad of public and private actors to tackle global development challenges (ODI 2013). As Humphrey (Humphrey 2011a) stresses, there are two strategies that are particularly important to strengthen global governance and sufficiently meet these new challenges: (1) increasing the density of networks in order to create opportunities for interchange and the development of ideas, and increasing the capacity of global institutions such as the G20 and (2) ceding space to emerging powers in international organisations such as the UN Security Council, the World Bank and the International Monetary Fund. This, Humphrey argues, would not necessarily imply a loss of influence but would increase the effectiveness of the organisations. Two examples reveal, however, how difficult these strategic partnerships might be to achieve for the EU within this new context. Carbone (2011) shows how the existence of three competing visions and goals within the EU (European Commission, European Parliament and member states) clashed to negatively affect the opportunity to constructively engage with China, the newest leading and rising global donor. Helly (2013), assessing the EU-Africa partnership, argues that a growing "continental drift" is in the making due to the limitations and inefficacies (now under review) of the 2007 Joint Africa Europe Strategy.

The EU likes to be perceived as a normative power, but the need to accommodate the different views and goals of a bloc, far from being monolithic, ultimately undermines its leadership in attempting to shape international development policies. This is particularly clear in the bloc's leading countries that run their own foreign policy, with still significant differences in their approaches to the new and challenging global order, and a dominant tendency to return to the principle of "national interest" rather than that of convergence in the EU foreign policy. Since the end of the 2000s, the ongoing structural changes in the EU institutional framework and the emergence of a new international aid scenario reveals a volatile EU development policy that is failing to match discourse with practice. In consequence, the EU seems to be now losing credibility and capability to engage with partner countries that are increasingly turning to new emerging donors.

\section{Bibliographic references}

African Development Bank (2011a). African Statistical Yearbook 2011, http://www.afdb.org/ fileadmin/uploads/afdb/Documents/Publications/Yearbook\%202011_web.pdf, accessed 4 April 2012.

African Development Bank (2011b). "India’s Economic Engagement with Africa." Africa Economic Brief2 (6).

African Union (2012). Report: EPA Negotiations Coordination Meeting (TI/TD/EPA/01), Arusha (Tanzania), 17 and 18 May 2012, http://au.int/en/dp/ti/sites/default/files/Aide\%20 Memoire\%20en.pdf, accessed 3 June 2012. 
Aggestam, L. (2008). “Introduction: ethical power Europe?” International Affairs 84 (1): 1-11. Alden, C., Daniel L. and R. S. de Oliveira, eds (2008). China Returns to Africa: A Rising Power and a Continent Embrace. London: Hurst and Company.

Bayne, N. and S. Woolcock (2011). The new economic diplomacy: decision-making and negotiation in international economic relations. London: Ashgate Pub Co.

Blunt, P., M. Turner, et al. (2011). “The Meaning of Development Assistance.” Public Administration and Development 31 (3): 172-187.

Börzel, Tanja A. and C.Hackenesh (2013).”Small carrots, few sticks: EU good governance promotion in Sub-Saharan Africa." Cambridge Review of International Affairs 26 (3): 536-555.

Cargill, T. (2011). "More with Less: Trends in UK Diplomatic Engagement in Sub-Saharan Africa." Africa Programme Paper 2011/03, Chatham House.

Carbone, Maurizio (2010). "Development Policy, The Treaty of Lisbon and the EU's role in the International Arena.” EUSA Review, Winter 2010: 11-15. http://www.eustudies.org/files/ eusa_review/winter2010final.pdf, accessed 15 July 2013.

Carbone, Maurizio (2010a).”The European Union, Good Governance and Aid Co-ordination.” Third World Quarterly 31 (1): 13-29.

Carbone, Maurizio (2011). "The European Union and China's rise in Africa: Competing visions, external coherence and trilateral cooperation." Journal of Contemporary African Studies 29 (2): 203-221.

Carbone, Maurizio (2013). "Policy Arena - Rethinking ACP-EU Relations After Cotonou: Tensions, Contradictions, Prospects." Journal of International Development (25): 742-756.

Carbone, Maurizio (2013a). "International development and the European Union's external policies: changing contexts, problematic nexuses and contested partnerships." Cambridge Review of International Affairs 26 (3): 483-496.

Carbone, Maurizio and J. Orbie (2014). "Beyond Economic Partnership Agreements: the European Union and the trade-development nexus." Contemporary Politics 20 (1): 1-9.

Casse, T. and S. Jensen (2009). “Do We Understand the Linkages between Economic Growth, Poverty Targets and Poverty Reduction?” Review of African Political Economy 36 (122): 539-553.

Castillejo, Claire, Ed. (2014). "New donors, new partners? EU strategic partnerships and development." European Strategic Partnerships Observatory Report (ESPO) 3 (December). http://fride.org/download/ESPO_EU_strategic_partnerships_and_development.pdf. accessed 7 July 2015.

CONCORD (2012). Future EU External Action Budget: Focus on Development, CONCORD, http://www.bond.org.uk/data/files/EU_/MFF/CONCORD_MFF_publication-March_2012. pdf, accessed 4 April 2012.

CONCORD (2012a). "Making Sense of EU Development Cooperation Effectiveness." CONCORD AidWatch Special Report On the post-Busan development effectiveness agenda, http:// aidwatch.concordeurope.org/static/files/assets/bc1e99da/report.pdf, accessed 19 July 2013.

Cornelissen, S. (2010). "Policy Coherence for Development in the European Union: The Case of the Economic Partnership Agreements." MA Thesis, University of Twente http://essay. utwente.nl/60286/1/MA_thesis_S_Cornelissen.pdf, accessed 4 April 2012. 
Craig, D. and D. Porter (2006). Development beyond neo-liberalism. Governance, poverty reduction and political economy. London: Routledge.

Davies, M., H. Edinger et al. (2008). "How China delivers development assistance to Africa." Research paper Centre for Chinese Studies, University of Stellenbosch, prepared for DFID, http:// www.ccs.org.za/downloads/DFID_FA_Final.pdf, accessed 4 April 2012.

Dyer, Geoff, Jamil Anderlini and Henny Sender (2011), "China Lending Hits New Heights." The Financial Times, 17 January, http://www.ft.com/intl/cms/s/0/488c60f4-2281-11e0-b6a200144feab49a.html\#axzz1 mazUxvJE, accessed 4 April 2012.

ECOSOC (2008). Trends in South-South and triangular development cooperation: background study for the Development Cooperation Forum. New York: United Nations.

EURODAD (2011). "Aid effectiveness: European Commission puts Europe in tough situation for Busan.” http://eurodad.org/4657/, accessed 4 April 2012.

European Commission (2005). Policy Coherence for Development. Accelerating progress towards attaining the Millennium Development Goals. COM(2005) 134 final, Brussels, 12.04.2005 http://eur-lex.europa.eu/LexUriServ/LexUriServ.do?uri=COM:2005:0134:FIN:EN:PDF, accessed 4 April 2012.

European Commission, European Parliament et al. (2006). The European Consensus on Development. OJEU (2006/C 46/01), http://eur-lex.europa.eu/LexUriServ/LexUriServ. do?uri=COM:2011:0637:FIN:EN:PDF, accessed 4 April 2012.

European Commission (2007). EU Code of Conduct on Division of Labour in Development Policy. $\operatorname{COM(2007)~} 72$ final, Brussels, 28.02.2007, http://eur-lex.europa.eu/LexUriServ/LexUriServ. do?uri=COM:2007:0072:FIN:EN:PDF, accessed 4 April 2012.

European Commission (2010). GREEN PAPER on EU development policy in support of inclusive growth and sustainable development. Increasing the impact of EU development policy. $\mathrm{COM}(2010)$ 629 final, Brussels, 10.11.2010 http://ec.europa.eu/europeaid/how/public-consultations/5241_ en.htm, accessed 4 April 2012.

European Commission (2011a). The Future Approach to EU Budget Support to Third Countries. $\operatorname{COM}(2011) 638$ final, Brussels, 13.10.2011, http://eur-lex.europa.eu/LexUriServ/LexUriServ. do?uri=COM:2011:0638:FIN:EN:PDF, accessed 4 April 2012.

European Commission (2011b). Increasing the Impact of EU Development Policy: An Agenda for Change. COM(2011) 637 final, Brussels, 13.10.2011, http://eur-lex.europa.eu/LexUriServ/ LexUriServ.do?uri=COM:2011:0637:FIN:EN:PDF, accessed 4 April 2012.

European Commission (2013). "Development and Cooperation-EuropeAid website." http:// ec.europa.eu/europeaid/index_en.htm, accessed 25 August 2013.

European Commission (2013a). Report from the Commission to the European Parliament, the Council, the European Economic and Social Committee and the Committee of the Regions on the EU Support for Democratic Governance, with a focus on the Governance Initiative. COM (2013) 403 final, Brussels, http://www.ipex.eu/IPEXL-WEB/dossier/document/COM20130403.do, accessed 20 August 2013.

European Commission (2014). "Communication from the Commission to the European Parliament, the Council, the European Economic and Social Committee and the Committee of the Regions: A Stronger Role of the Private Sector in Achieving Inclusive and Sustainable Growth. "In Developing Countries. COM (2014) 263 final, Brussels. http://ec.europa.eu/ transparency/regdoc/rep/1/2014/EN/1-2014-263-EN-F1-1.Pdf, accessed 7 July 2015. 
European Parliament (2008). European Parliament resolution on China's policy and its effects on Africa of 23 April 2008 (2007/2255(INI)), www.europarl.europa.eu, accessed 4 April 2012.

European Think Tanks Group (2014).“Our Collective Interest: Why Europe's problems need global solutions and global problems need European action." September, http://www.odi.org/sites/odi. org.uk/files/odi-assets/publications-opinion-files/9136.pdf, accessed 10 July 2015.

European Union. "Treaty of Lisbon." Official Journal of the European Union, volume 50 (17 December 2007). http://bookshop.europa.eu/is-bin/INTERSHOP.enfinity/WFS/EUBookshop-Site/en_GB/-/EUR/ViewPublication-Start?PublicationKey=FXAC07306, accessed 2 August 2013.

European Union External Service, EEAS Review (2013). http://eeas.europa.eu/library/ publications/2013/3/2013_eeas_review_en.pdf, accessed 9 July 2015.

Eurostat (2010). Africa-EU - economic indicators, trade and investment, http://epp.eurostat. ec.europa.eu/statistics_explained/index.php/Africa-EU_-_economic_indicators,_trade_and_ investment, accessed 4 April 2012.

Fagersten, Bjorn et al. (2014)."Towards a European Global Strategy. Securing European Influence in a Changing World.” IAI/PISM/RIE/UI, http://www.iai.it/sites/default/files/ egs_report.pdf, accessed 10 July 2015.

Faure, Raphaelle, Mikaela Gavas \& Simon Maxwell (2013). The Review of the European External Action Service: A commentary on the report (Overseas Development Institute:London). http://www.odi.org/publications/7795-european-external-action-services-eeas-reviewcommentary-faure-gavas-maxwell, accessed 9 July 2015.

Faust, J. (2010). "Policy Experiments, Democratic Ownership and Development Assistance." Development Policy Review 28 (5): 515-534.

Freemantle, S. and J. Stevens (2012). "EM10 and Africa: China-Africa — taking stock after a decade of advance." Africa Macro: Insight \& Strategy, Standard Bank.

Gavas, M. (2012). “The European Commission's legislative proposals for financing EU Development Cooperation." Overseas Development Institute (ODI), Background Note February, http://epp.eurostat.ec.europa.eu/statistics_explained/index.php/Africa-EU___economic_ indicators,_trade_and_investment,accessed 4 April 2012.

Gavas, M., S. Koch et al. (2011). The EU's Multi-Annual Financial Framework post-2013: Options for EU development cooperation. European Think Tanks Group, June, http://epp.eurostat. ec.europa.eu/statistics_explained/index.php/Africa-EU_-_economic_indicators,_trade_and_ investment, accessed 23 March 2012.

Gibert, M. V. and N. Bagayoko (2009). "The European Union in Africa: the linkage between security, governance and development from an institutional perspective." Journal of Development Studies 45 (5): 789-814.

Glenn, J. (2008). "Global Governance and the Democratic Deficit: stifling the voice of the South.” Third World Quarterly 29 (2): 217-238.

Glennie, J. (2011). "Busan has been an expression of shifting geopolitical realities." The Guardian, Friday 2 December 2011, http://www.guardian.co.uk/global-development/poverty-matters/ 2011/dec/02/busan-shifting-geopolitical-realities, accessed 4 April 2012.

Gore, Charles. (2013). “The New Development Cooperation Landscape: Actors, Approaches, Architecture." Journal of International Development 25: 769-786. 
Hackenesch, Christine and Heiner Janus (2013). "Post-2015: How Emerging Economies Shape the Relevance of a New Agenda." Briefing Paper 14, German Development Institute, http://www.die-gdi.de/CMS-Homepage/openwebcms3_e.nsf/(ynDK_contentByKey)/ANES98DFEB/\$FILE/BP\%2014.2013.pdf, accessed 13 July 2013.

Helly, Damien (2013). “The EU and Africa since the Lisbon summit of 2007: Continental drift or widening cracks?”, South African Journal of International Affairs 20 (1): 137-157.

HTSPE (2009). Aid Effectiveness Agenda: Benefits of a European Approach. Project No. 2008/170204 - Version 1. http://ec.europa.eu/europeaid/sites/devco/files/report-benefits-aideffectiveness-20091023_en_5.pdf. accessed 4 April 2012.

HTSPE (2011). Report on the consultation on the Green Paper on "EU Development Policy in support of inclusive growth and sustainable development — Increasing the impact of EU development policy." Project No. 2010/252309 - Version 1. https:/ec.europa.eu/europeaid/sites/devco/files/ report-on-consultation-green-paper-inclusive-growth-sustainable-development-2010_en.pdf, accessed 4 April 2012.

Humphrey, J. (2011a). “European Development Cooperation to 2020: Rising Powers and New Global Challenges.” Policy Brief6 (January), Brighton: Institute of Development Studies (IDS).

Krätke, Florian (2013. "From Purse to Policy to Practice: Six Initiatives to Future-proof EU Development Cooperation for 2014-2020 and Beyond?” ECDPM Briefing Note 51, ECDPM June, http://ecdpm.org/publications/purse-policy-practice/, accessed 9 July 2015.

Kragelund, P. (2008). "The return of non-DAC donors to Africa: New Prospects for African Development?” Development Policy Review 26 (5): 555-584.

Mawdsley, Emma (2012).From Recipients to Donors: Emerging Powers and the Changing Development Landscape. London: Zed Books

Moncrieff, R. (2012). "French Relations with Sub-Saharan Africa under President Sarkozy." Occasional Paper 107, SAIIA January, http://www.saiia.org.za/occasional-papers/french-relationswith-sub-saharan-africa-under-president-sarkozy, accessed 29 August 2013.

ODI (2013). "EU development cooperation. Where have we got to? What's next?” Report on a conference for EU Change-makers held at ODI, London (24-25 June 2013), http://www.odi.org. uk/sites/odi.org.uk/files/odi-assets/publications-opinion-files/8498.pdf, accessed 2 August 2013.

OECD (2005). Paris Declaration on Aid Effectiveness: Ownership, Harmonisation, Alignment, Results and Mutual Accountability. http://www.oecd.org/dataoecd/11/41/34428351.pdf, accessed 4 April 2012.

OECD (2008). Accra Agenda for Action. http://www.oecd.org/document/18/0,3746, en_2649_336398_35401554_1_1_1_1,00.html, accessed 4 April 2012.

OECD (2011). Busan partnership for effective development cooperation. http://www. aideffectiveness.org/busanhlf4/images/stories/hlf4/OUTCOME_DOCUMENT___FINAL_ EN.pdf, accessed 4 April 2012.

OECD (2012). European Union. Development Assistance Committee (DAC) Peer Review 2012. http://www.oecd.org/dac/peer-reviews/50155818.pdf, accessed 27 July 2013.

Smith, K., T. Yamashiro Fordelone et al. (2010). "Beyond the DAC: The welcome role of other providers of development co-operation.” DCD Issues Brief May 2010, OECD Development Co-operation Directorate Paris. 
Smith, Michael E. (2013). "The European External Action Service and the security-development nexus: organizing for effectiveness or incoherence?” Journal of European Public Policy 20 (9): 1299-1315.

Smith, Michael E. (2011). "A liberal grand strategy in a realist world? Power, purpose and the EU's changing global role.” Journal of European Public Policy 18 (2): 144-163.

Stahl, A. (2011). "Contrasting Rhetoric and Converging Security Interests of the European Union and China in Africa." Journal of Current Chinese Affairs 40 (4): 147-173.

Vanhoonacker, Sophie and Karolina Pomorska (2013). "The European External Action Service and agenda-setting in European Foreign Policy." Journal of European Public Policy 20 (9): 1316-1331.

Walz, J. and V. Ramachandran (2011). "Brave New World: A Literature Review of Emerging Donors and the Changing Nature of Foreign Assistance." Working Paper 273, Washington: Center for Global Development, http://www.cgdev.org/files/1425691_file_Walz_ Ramachandran_Brave_New_World_FINAL.pdf, accessed 15 June 2013.

Withney, Nick et al. (2014). "Rebooting EU foreign policy." ECFR Policy Brief 114, Brussels: EFCR, http://www.ecfr.eu/page/-/ECFR114_EU_BRIEF_SinglePages_(1).pdf, accessed 10 July 2015.

\title{
Acknowledgements
}

I would like to thank Raquel Freitas from CIES-ISCTE in Portugal for her valuable contributions to this paper.

\begin{abstract}
The European Union (EU) is one of the world's leading donors in official development assistance (ODA) to give a strong weight in the relationship with recipient partner countries, in particular with those that are more dependent on it. Besides the material weight of its funding, the EU has retained historical ties and influence in diplomatic, political and economic terms in many of its ODA recipient partner countries (particular in Sub-Saharan Africa). Since the 2000s, the EU development policy has not only undergone major structural changes in its institutional framework but also has started to face a new international aid scenario. This paper explores why a normative-based EU development policy is being challenged by reformed EU institutions and a new global order, and how the EU is attempting to respond to this context in face of the deepest recession since the end of the Second World War.
\end{abstract}

Keywords: European Integration, European Union Agenda for Change, European Union Development Policy, European Union reforms, New Global Order.

\section{Resumo}

A União Europeia (UE) é um dos maiores doadores mundiais de ajuda pública ao desenvolvimento (APD) a conferir um peso importante à sua relação com os países parceiros beneficiários, em particular com aqueles que são mais dependentes da ajuda concedida. Além do peso material do 
seu financiamento, a UE mantém laços históricos e influência diplomática, política e econômica em muitos dos países receptores de ajuda ao desenvolvimento (particularmente os da África Subsaariana). Desde os anos 2000, a política de desenvolvimento da UE não só tem sofrido grandes mudanças estruturais em seu quadro institucional, mas também começou a enfrentar um novo cenário de ajuda internacional. Este artigo explora os motivos pelos quaius a política de apoio ao desenvolvimento está sendo desafiada por instituições da própria UE, e como a organização está tentando responder a esse desafio, no contexto da mais profunda recessão econômica desde o fim da Segunda Guerra Mundial.

Palavras-chave: Integração europeia, a agenda da União Europeia para a Mudança, Política de Desenvolvimento da União Europeia, reformas da União Europeia, da Nova Ordem Mundial.

Received: July 15, 2015 Accepted: October 10, 2015 